\title{
WEATHERING STAGE CONTROL OF TUFF AND ITS INFLUENCE TO THE MALINO-MANIPI LANDSLIDE SUSCEPTIBILITY, SOUTH SULAWESI INDONESIA
}

\author{
Busthan*1, A.M. Imran ${ }^{2}$, L. Samang ${ }^{1}$, and M. Ramli ${ }^{2}$ \\ ${ }^{1}$ Department of Civil Engineering, Faculty of Engineering, Hasanuddin University \\ ${ }^{2}$ Department of Geology Engineering, Faculty of Engineering, Hasanuddin University
}

\begin{abstract}
In 2013 there has been 34 incidents of landslides which cut the roads linking between Gowa and Sinjai off. The purpose of this study was to determine the effect on the stage of weathering of landslide in the study area. Methods used in this study are field survey, petrographic analysis, XRD analysis and shear strength testing of rock. Field survey results indicates that the area is dominated by tuffs that are partly volcanic breccia and lava. Petrographic analysis, showing the dominant composition of tuff with volcanic glass, bitownite, pyroxene and opaque minerals, and XRD analysis results indicate weathering tuffs that have experienced high and completely weathered contain smectite and halloysite clay types, and insitu shear strength test results indicate a strong shift to the lower tuff with high stage of weathering.
\end{abstract}

Keywords: Susceptability to landslides, the stage of weathering, halloysite and smectite, shear strength, roads of Malino-Manipi

\section{Introduction}

Landslide susceptibility is a phenomenon which conditions a slope or be potentially prone to move. Although at this point the slope is stable, but if there is a trigger that will soon

${ }^{*}$ Corresponding author: BUSTHAN, Department of Civil Engineering, Faculty of Engineering, Hasanuddin University. E-mail: bazikin@yahoo.com be moving or landslides may occur (Karnawati, 2005).

Malino-Manipi road is one road which is prone to landslides (Samang et al., 2007), and according to Busthan et al. (2012), the causes of landslides in the area of West Sinjai are influenced by the steep slope, rock constituents of Pleistocene Age and the presence of discontinuities in the rock fields that tend to occur in the direction of the slope. Furthermore Imran et al. (2012) concluded that the cause of the landslide susceptibility of the Malino - Manipi roads caused by an existing condition of a steep slope $350-80 \mathrm{o}$, composed by young volcanic rocks that have not been perfectly compacted, rock conditions experienced strong weathering. Also according to Imran et al. (2012), the incidence of landslides due to the susceptability of the stratigraphic position of the rocks making up the study site occurred intercalation between permeable rocks (tuffs and volcanic breccias) and impermeable rock (lava). Based on the analysis of the AHP by Solle (2012), concluded that the main factors of landslides in the watershed Jeneberang is due to the steep slope and lithology.

Recent data shows that during the period of January - July 2013 landslide had occurred in 34 locations. The lithology experiencing landslides generally occur in volcanic tuff rock. The landslide caused the accumulation and destruction of the road so that the flow of public trans- 
port and the economy was disturbed. In addition to damaging the landslide also destroyed gardens and fields belonging to the community with considerable material losses. In addition to damaging the road, the landslide also destroyed gardens and fields belonging to the community with considerable material losses.

Many methods are used by researchers to assess the landslide susceptibility among others are Wati et al. (2010), applying heuristic approach in landslide susceptibility mapping in Tawangmangu area of Central Java which uses 6 parameters, namely slope, lithology, soil depth, texture, permeability and land use. Gemitzi et al. (2011), using environmental factors, Fuzzi membership functions and GIS.

Another approach in assessing landslide susceptibility is to use empirical classification based on the condition of the field of rock discontinuities. Tomas et al. (2011) suggested that originated from the classification of Rock Mass Rating (RMR, Bieniawski, 1976), known by the geomechanics classification, then yielded several classifications such as Rock Mass Strength (RMS, Selby, 1980), Slope Mass Rating (Romana, 1985), Slope Rock Mass Rating (SRMR, Robertson, 1988), Mining Rock Mass Rating (MRMR, Halmes and Terbrugge , 1991), Chinese Slope Mass Rating (CSMR, Chen, 1995) and others. All of the above classification intends to determine the quality of the rock mass in order to determine the stability of the rock or soil slopes.

In this study, researchers will conduct a study based on the level of rock weathering, tuff composition of fresh tuff using a polarizing microscope, the composition of weathered tuff and XRD analysis based on the shear strength of weathered tuff using direct field testing (in situ test, vane shear test). This study has tried to see the relationship between the composition of fresh tuff, the composition of weathered tuff and the shear strength, thus urgent research conducted for the study site consists predominantly of tuff (Sukamto and Surpriatna, 1982) and this research titled Weathering Stage Controls of Tuff and Its Influence To The Malino-Manipi Landslide Susceptibility South Sulawesi Indonesia.

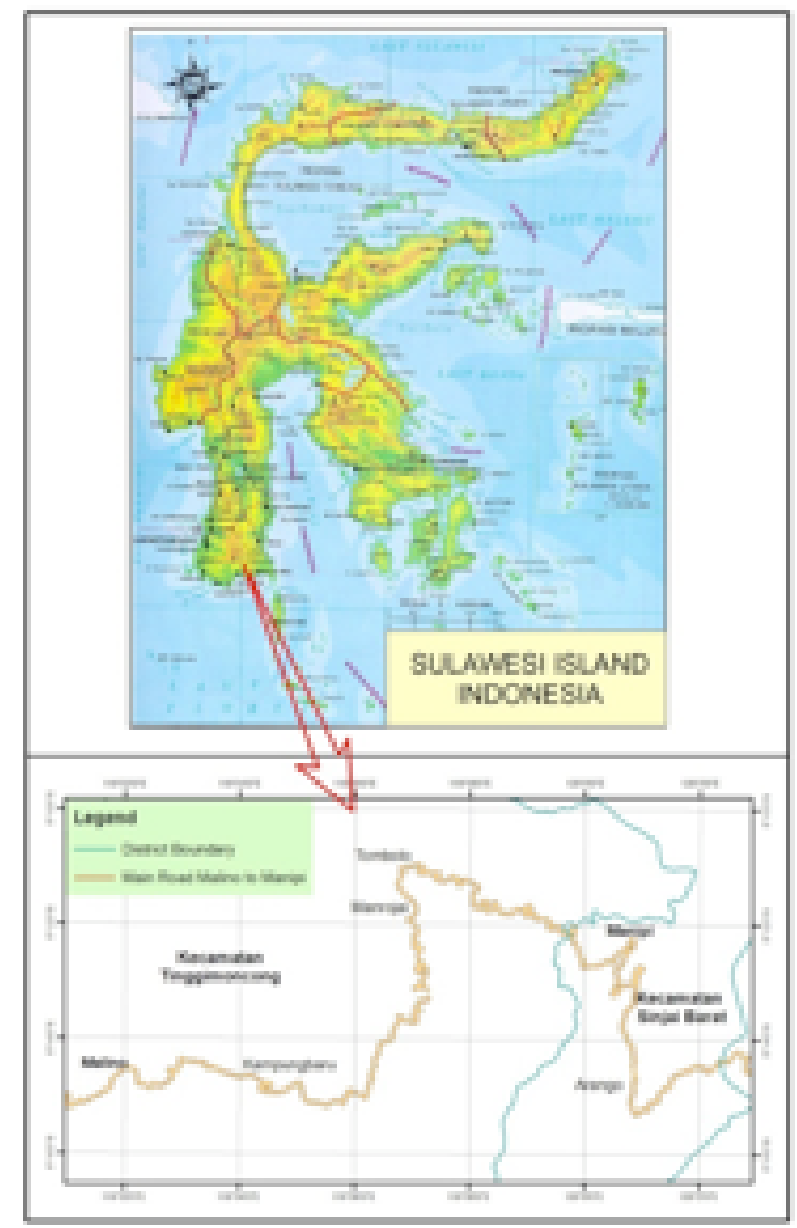

Figure 1: Study area map.

\section{Study area}

Location of the study area is located on the road Malino-Manipi, which connects Regional Tourism Malino Gowa and Manipi of West Sinjai Sinjai (Figure ). The research area is the eastern slopes of Mount Lompobattang. The study site is about $100 \mathrm{~km}$ distance from Makassar. Altitude between 700 meters to 1600 meters above sea level (mean sea level).

\section{Methodology}

The study was conducted at locations that have experienced landslides and the steep slopes are expected to experience landslides with slopes compiled by tuff. The purpose of this research is to know the effects of weathering stage on slope landslide susceptibility tuff. To determine the cause of the landslide susceptibility, two ap- 
proaches were conducted field surveys and laboratory analysis. Field surveys include identifying the point of landslides, semi-detailed geological mapping and the measurement of the shear strength at 4 locations weathered tuff landslide. This measurement is done by sliding the fan method (vane shear test). Laboratory analysis of tuff petrographic analysis carried out on 4 samples in Laboratory of Geological Engineering Faculty of Engineering, UNHAS and X-Ray Diffraction analysis (XRD) of the weathered tuff and completely weathered tuff, each of the 2 samples were prepared and analyzed in Gajah Mada University (UGM) Integrated Geology Laboratory.

\section{Results}

\subsection{Tuff characteristics}

Field survey results indicate that the tuff profile consists of 6 levels (stages). They are fresh tuff, slightly weathered tuff, moderately weathered tuff, highly weathered tuff, completely weathered tuff and residual soil. Field description of each condition are as follows. Fresh tuff profile characteristic; indication of weathering is still not yet shown, fresh look and no changes in color, the color is light gray to dark gray; characteristics slightly weathered tuff is there has been a change in color on the rocks body and on small existing disintegration of becoming soil, it can be cut with a knife "cutter" or can be cut with a finger nail, tuff color is reddish gray, rock textures are still unclear; characteristics of highly weathered tuff is change in color of the tuff and cracks that have been red-grayish in color, generally the tuff can be clipped by finger nails or fingers, rock textures are hardly recognizable. Characteristics of completely weathered tuff is almost the whole body of rock has been turned into a red to brownish red color, the texture of the rock is very hard to recognize, rocks are easily taken with the hand and last type of tuff is the characteristics of the residual soil. The tuff is turning everything into soil, the color from reddish brown to brown, texture and the structure can no longer be observed but have not yet transported.

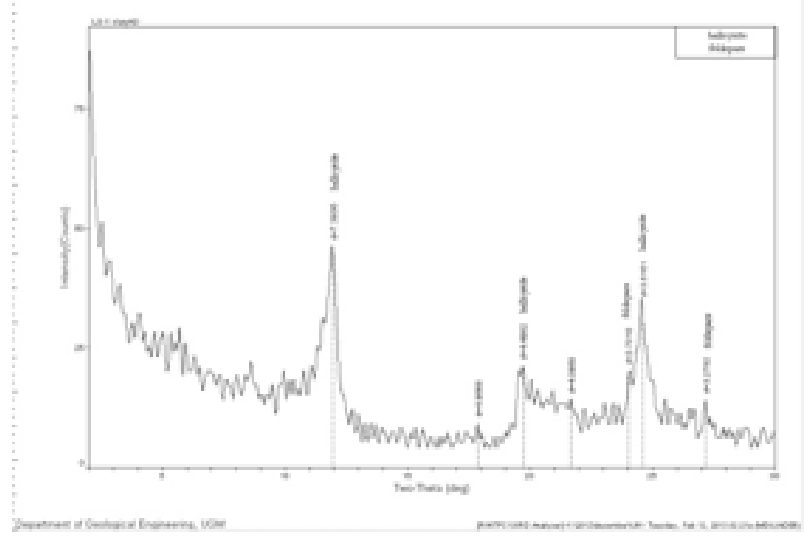

Figure 3: X-Ray Diffraction pattern of highly weathered Tuff mineral composition.

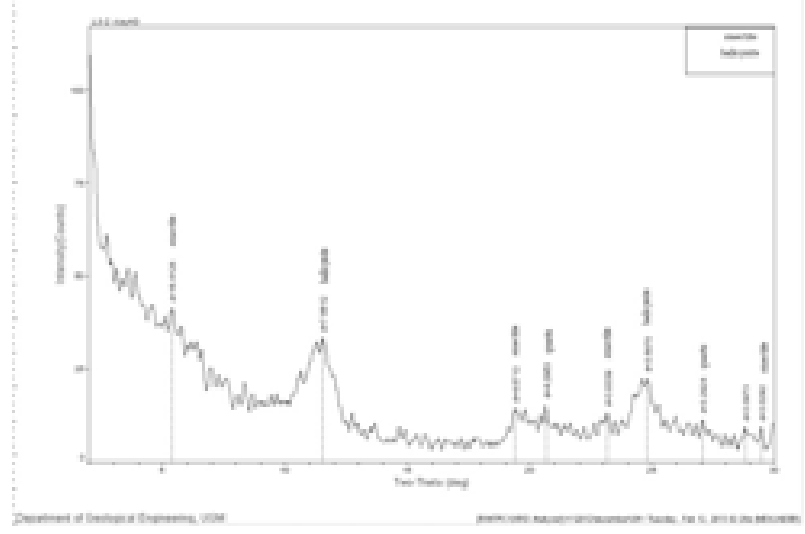

Figure 4: X-Ray Diffraction pattern of completely weathered Tuff mineral composition.

\subsection{Mineral composition of tuff}

Petrographic observations indicate the composition of tuff varies. Based on data from the mineral composition of the tufa form four different samples, it shows that the general composition of the mineral is volcanic glass, bitownite, pyroxene and opaque minerals (Figure 2 and Table 1).

\subsection{Composition of weathered tuff}

X-Ray Diffractometer analysis results of 4 samples of highly weathered rocks and completely weathered rocks suggests that it has weathered tuff containing clay minerals of halloysite and smectite type (Figures $3-4$ ). 

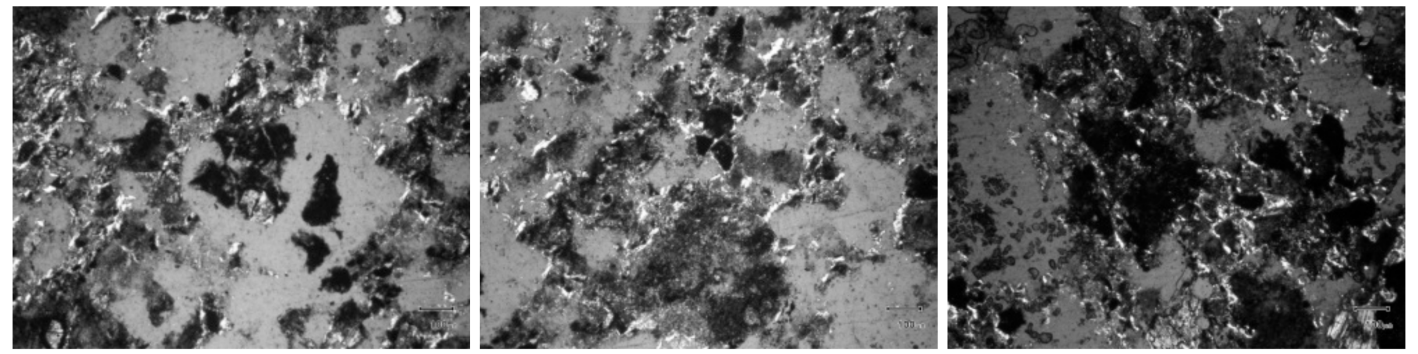

Figure 2: Tuff thin section, consist of volcanic glass, bitownite, pyroxene and opaque minerals.

Table 1: Mineralogical composition of Tuff by petrographic observation.

\begin{tabular}{|l|c|c|c|c|}
\hline \multirow{2}{*}{\multicolumn{1}{|c|}{ Mineral Name }} & \multicolumn{4}{c|}{ Mineral composition (\%) } \\
\cline { 2 - 5 } & Sample 1 & Sample 2 & Sample 3 & Sample 4 \\
\hline Plagioclase (labradorite) & 17 & 10 & 15 & 15 \\
\hline Pyroxene & 13 & 9 & 15 & 9 \\
\hline Volcanic Glass & 67 & 79 & 65 & 70 \\
\hline Opaque Mineral & 3 & 2 & 5 & 6 \\
\hline & 100 & 100 & 100 & 100 \\
\hline
\end{tabular}

\subsection{Shear strength of weathered rocks and residual soil}

Vane shear test was performed in situ on the moderately weathered tuff, highly weathered, completely weathered and soil residual. The vane shear test results on weathered rock and soil residues are presented in Table 2 .

\section{Discussion}

Lithology that covers an area whether being exposed or lies near to the surface of the earth will experience the process of weathering, although the process is slow, but very significant in influencing engineering properties of the rocks (Sadisun, 1998). Weathering process consists of mechanical or physical weathering, chemical weathering and organic weathering (Undul, 2012).

Tuffs that constituent the slopes in the study site has experienced weathering ranging from moderately weathered to a state of soil as had been previously described above, and generally have highly until completely weathered and residual soil. One of the reasons is because the composition of rock dominated by volcanic glass, plagioclase types of labradorite and pyroxene. Based on the mineral composition, which make up the tuff, in the research sites, is considered to be basaltic tuffs. This kind of composition will greatly support the rapid weathering. According Eggleton et al. (1987) rocks that contains a lot of volcanic glass is very easily weathered, and Undul (2012) says that the rocks that contain big amount of alkaline minerals will be susceptible to weathering. Moreover, the existing conditions of the tuff is not yet compacted and this the characteristics of old volcanic rocks of Lompobattang age of Pleistocene (Sukamto and Supriatna , 1982).

Due to the highly until completely weathered condition, tuff composition will change with the dominant composition of smectite and halloysite. Smectite clay mineral species is a type of clay that easily expands when high water content and very low shrinkage when water content is low (Gates, et al., 1993).

Based on testing using the vane shear test method, we drew the graph showing the correlation between the weathering level of rocks and the shear strength the weathered tuff (Figure 5). In Figure 5, we can see that if the tuffs 
Table 2: Shear strength of weathering stage of Tuff.

\begin{tabular}{|l|c|c|c|c|}
\hline $\begin{array}{l}\text { WEATHERING } \\
\text { STAGES }\end{array}$ & $\begin{array}{c}\text { Shear Strength } \\
\text { Location-1 } \\
\mathrm{Kg} / \mathrm{cm}^{2}\end{array}$ & $\begin{array}{c}\text { Shear Strength } \\
\text { Location-2 } \\
\mathrm{Kg} / \mathrm{cm}^{2}\end{array}$ & $\begin{array}{c}\text { Shear Strength } \\
\text { Location-3 } \\
\mathrm{Kg} / \mathrm{cm}^{2}\end{array}$ & $\begin{array}{c}\text { Shear Strength } \\
\text { Location-4 } \\
\mathrm{Kg} / \mathrm{cm}^{2}\end{array}$ \\
\hline $\begin{array}{l}\text { Moderately } \\
\text { Weathering (MW) }\end{array}$ & $>3$ & $>3$ & $>3$ & $>3$ \\
\hline $\begin{array}{l}\text { High Weathering } \\
\text { (HW) }\end{array}$ & 0.69 & 0.80 & 0.91 & 1.09 \\
\hline $\begin{array}{l}\text { Completely } \\
\text { Weathering (CW) }\end{array}$ & 0,52 & 0.58 & 0.65 & 0.34 \\
\hline Residual Soil (RS) & 1.18 & 1.90 & 1.77 & 1.67 \\
\hline
\end{tabular}

experience weathering ranging from moderately weathered to highly weathered, the shear strength will become smaller and increases again after it becomes soil residue. The lowest shear strength will occur after the rock been perfectly weathered tuff. The cohesion of weathered rock will decrease, as well as friction angle will become smaller, thus the shear strength will become smaller. Durgin (1977) stated that the weathering of the rocks is causing a decrease in shear strength, and Saveny (2002, in Karnawati, 2007) asserts that the factors derived from the slopes of debilitating conditions such as weathering of rocks and will be able to trigger landslides. Thus when the rock has been highly weathered to completely weathered then slopes where the rocks are going to be prone to landslides and the lowest shear strength zone will become the plane fealure.

\section{Conclusion}

Conclusions that can be drawn from this study are: 1) Mineral composition of the alkaline tuff is crucial in determining the stage of weathering, as well as the level of rock lithitification or the compactness of the rocks; 2) When tuff experienced weathering it will decomposed becomes halloysite minerals and smectite clay with characteristics of high to very high expanding and shrinking properties and weathered tuff weathered completely unstable when the water level is high; 3) Slopes which are built upon highly weathered tuff to completely weathered is the most prone to landslides due to its very low shear strength.

\section{References}

Busthan, Imran A.M., Samang L., and Ramli M. (2012) Geological Control and Mitigation Of Malino-Manipi Landslide, South Sulawesi Indonesia, In Proceeding International Conference On Construction Industry, Facilities and Asset Management, November 22 - 23, 2012 Padang-Indonesia.

Delvi M. (2010) The Geology of The Magala Area, West Sinjai District, Regency of Sinjai, South Sulawesi Province (Report of Geological Mapping) Department of Geological Engineering, Hasanuddin University (In Indonesian, Unpublished).

Durgin Ph.B. (1977) Landslide and weathering of Granitic Rock, Geological Society Of America, Reviews In Engineering Geology, Volume III. California USA.

Gates W.P., Wilkinson H.T. and Stucki J.W. (1993) Swelling Properties Of Microbially Reduced Ferrugenous Smectite, Clays and Clay Minerals Journal, Vol. 41, No. 3, pp 360 - 364 . USA.

Gimitzi A., Falalakis G., Eskioglou P. and Patalas (2011) Evaluating Landslide Susceptibility Using Environmental Factors, Fuzzi Membership Fucntion and GIS, Global Nest Journal Vol 13 pp 28 - 40, 2011

Eggleton R.A., Foudoulis Ch. And Varkevisser 


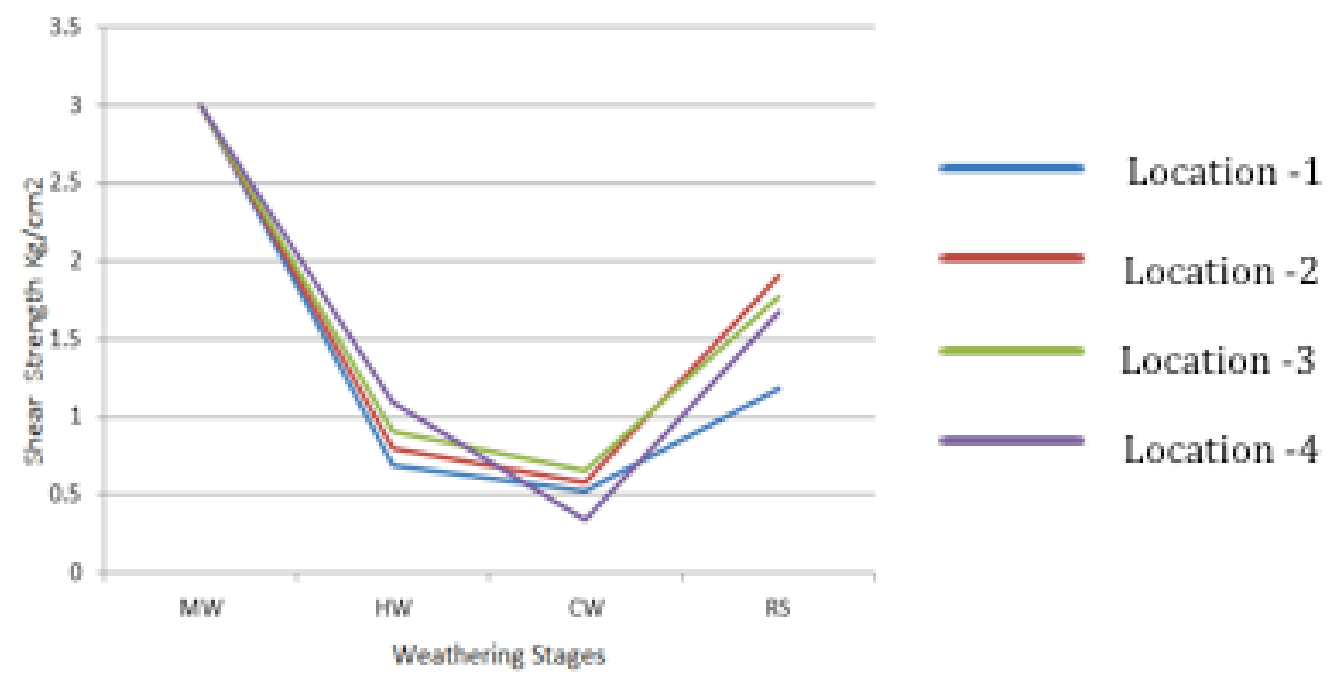

Figure 5: Graph showing the relationship between shear strength and weathering stage of tuff.

D. (1987) Weathering Of Basalt : Changes In Rock Chemistry and Mineralogy, Clay and Clay Mineral Journal, Vol. 35 No. 3, 161 169 ,

Imran A.M, Busthan and Sultan (2012) The Role Of Geological Aspects As Cause Of Landslide At Road Malino - Sinjai, Bulletin of Environment Geology Vol. 22 No. 3 December 2012, Ministry Of Energy and Mineral Resources, Geological Agency Centre of Groundwater Resources and Environmental Geology, Bandung.(In Indonesian).

Karnawati, D. (2005) Bencana Alam Gerakan Massa Tanah Di Indonesia dan Upaya Penanggulangannya, Jurusan Teknik Geologi Fakultas Teknik Universitas Gajahmada, Yogyakarta.

Karnawati D. (2007) The Mechanism of Rock Mass Movements as The Impact Of Earthquaqe: Geology Engineering Review and Analysis, Department of Geological Engineering, Engineering Faculty, Gadja Madah University, Yogyakarta (In Indonesian).

Keputusan Menteri Energi dan Sumber Daya Mineral No. 1452 K/10/MEM/2000, tanggal 3 November 2000.

Romana M., Jose R.S. and Enrique M. (2003) SMR Geomechanics Classification: Application, Experience and Validation, ISRM 2003Technology Roadmap for Rock machanics,
South African Institute of Mining and Metallurgy.

Sadisun I. A. (1998) Pengaruh Pelapukan Batulempung Formasi Subang Terhadap Beberapa Sifat Keteknikan Guna Menunjang Efektivitas Pemilihan Desain Perkuatan Lereng, Prosiding ITB, Vol. 30, No. 3. Bandung.

Samang L., Suharty T., and Mahmud A.F. (2007) Identification and Mapping of Landslide Prone Roads with GIS Base In South Sulawesi, Makassar, Agency for Regional Research and development (BALITBANDA) South Sulawesi Province, Makassar (In Indonesian).

Solle M. S., Mustafa M., Baja S. and Imran A.M. (2013) Landslide Susceptibility Zonation Model On Jeneberang Watershed Using Geographical System and Analytical Hierarchy Process, Interrnational Journal Of Engineering And Innovative Technology (IJEIT) Vol. 1, Issue 1, Brach Office India.

Sukamto R and Supriatna S. (1982) The Regional of Geological Map of Ujung Pandang, Benteng and Sinjai, Geological Research and Development Centre Ministry of Mines and Energy, Bandung.

Tomas R., Cuenca A., Cano M. and CarciaBarba J. (2011) A Graphical Approach For Slope Mass Rating (RMR), Journal Home Page www.Elsevier.com/locate/enggeo. Engineering Geology, Elsivier Undul O., (2012), 
Weathering Of Ultra Mafic Rocks, Istambul University, Geological Engineering, ETH, Zurich.

Varnes, D.J. (1978) Slope Movement Types and Processes, In Schuster, R.L. ang Krizek, R.J., Landslide Analysis and Control, Transportation Research Board, Special Report 176, National Academi of Sciences USA.

Wati S.E., Hastuti T., Widjoyo S. and Pinem F. (2010) Landslide Susceptibility Mapping with Reuristic Approach In Mountainous Area, A Case Study In Tawangmangu Sub
District, Central Java, Indonesia, International Archives Of The Photogrammetry, Remote sensing and spasial Information Science, Vol. XXXVIII, Part 8 Kyoto Japan.

William, Turner and Gilbert (1957) Petrography an Introduction to The Study Of Rock In Thin Section, Second Edition, W.H. Freeman and Company, New York.

Yowono (1989) Petrologi dan Mineralogi G. Lompobattang Jurnal Geologi Indonesia Vol. 12, No. 1, pp 483 - 509, Jakarta. 